\title{
THE RELATION OF THE LIME REQUIREMENTS OF SOILS TO THEIR RETENTION OF AMMONIA ${ }^{1}$
}

\author{
L. P. HOWARD \\ Rhode Island Agricultural Experiment Station. \\ Received for publication November 23, 1918
}

Several methods for determining the lime requirements of soils have been developed recently. New terms are being coined rapidly to designate various types of acidity which the methods propose to measure. A "lime requirement" determined by one method, in general may bear little relation to that secured by another.

The total amount of base removed by a soil from a solution of a neutral or alkaline salt is the resultant of at least two reactions proceeding simultaneously. These may be designated as (a) chemical fixation, and (b) physical absorption.

The number of basic ions removed from solutions of different bases will differ. In the first place, that removed for the neutralization of free acid is the same for various bases; but in many of our soils, the general idea is that the major portion of the base is retained by insoluble acid salts. Here an equilibrium is established. The extent to which the neutralization of these acid constituents proceeds before equilibrium is established depends upon (a) the activity of the base, or the extent to which it is ionized, (b) concentration, (c) temperature, and other factors.

What seems to be desired in a method for measuring "lime requirements" by the absorption of bases is that the neutralization of free acids shall be complete, and that the neutralization of the acid silicates shall proceed to about the same point for soils of quite different character before equilibrium is established.

It was this idea which prompted the work herein recorded. A study of various procedures has been made to see whether one could be developed which would give a "requirement". that would be, within reasonable limits, independent of (a) concentration of the base, (b) temperature, and (c) time of contact.

In adopting a base which would neutralize insoluble acid residues to about the same extent for soils of different reaction, the idea was held that to satisfy.

${ }^{1}$ Contribution 227 from the Agricultural Experiment Station of the Rhode Island State College, at Kingston, R. I. Read at the 1916 Convention of the Association of Official Agricultural Chemists. 
this condition there must be established, at the end of the reaction, circumstances in which no excess base should remain.

A volatile base, as ammonium hydroxide, suggested itself. The principle of the procedure was to treat the soil with ammonia water, evaporate to dryness, and measure the retained ammonia.

The procedure in detail as finally adopted, together with the effect of certain variations upon the absorption, are here recorded.

\section{DISTILLATION BY AERATION}

The aeration method seemed to possess desirable features for estimating small amounts of ammonia. However, as there is considerable discussion as to the virtues of this method, certain features had to be investigated. These were (a) selection of alkali, (b) aeration necessary, and (c) completeness of ammonia absorption.

a. Selection of alkali. Sodium carbonate, sodium hydroxide and magnesium oxide were used with the following results:

\begin{tabular}{|c|c|c|c|c|}
\hline \multirow{3}{*}{ ALKALI USED } & \multicolumn{4}{|c|}{$\mathrm{NH}_{3} \mathrm{RECOVERED}$} \\
\hline & \multicolumn{2}{|c|}{ Absorption bottles } & \multirow{2}{*}{ Blank soil } & \multirow{2}{*}{$\begin{array}{l}\text { Corrected } \\
\text { recovery }\end{array}$} \\
\hline & No. 1 & No. 2 & & \\
\hline & $m g m$. & mgm. & mgm. & $m g m$ \\
\hline $\mathrm{Na}_{2} \mathrm{CO}_{3}(5 \mathrm{gm})$. & 51.34 & -0.08 & 0.46 & 50.88 \\
\hline $\mathrm{NaOH}(2 \mathrm{gm}.) \ldots \ldots \ldots \ldots$ & 53.99 & 0.05 & 1.88 & 52.11 \\
\hline $\mathrm{MgO}(5 \mathrm{gm}.) \ldots \ldots \ldots \ldots \ldots$ & 48.68 & -0.05 & & 48.68 \\
\hline MgO (5 gm.) (distilling by boiling)........... & 51.14 & & 1.21 & 49.93 \\
\hline
\end{tabular}

The use of $\mathrm{NaOH}$ permitted a somewhat more rapid recovery of ammonia, but the amount evolved was subject to greater variation than that recorded by the use of $\mathrm{Na}_{2} \mathrm{CO}_{3}$.

Distillation by boiling with $\mathrm{MgO}$ yielded results quite similar to those ob-. tained by the use of sodium carbonate. The latter however, seemed to work very satisfactorily and was used as the alkali in connection with the results to be recorded.

b. Aeration necessary. With sodium carbonate as much ammonia was obtained by 18 hours aeration as by 60 hours, and the former period was adopted. Six determinations were conducted in a string and a current of 300 liters of air per hour [measured by the Kober method (1)] passed through the last flask.

c. Completeness of ammonia absorption. The figures recorded under (a) "Selection of alkali" indicate that the absorption is complete in the first bottle; that is, for amounts of ammonia up to $75 \mathrm{mgm}$., with the rate of aeration indicated.

These results indicate very clearly that the reaction which takes place between the soil and an aqueous solution of ammonia is rapid and is complete in one hour. 
Small variations in temperature do not appreciably affect the amount of ammonia retained. However, at the lower temperature it is much more difficult to secure duplicate determinations. Evidently at these temperatures

TABLE 1

Time of contact before evaporation, and its influence upon ammonia retained. (170 mgm. of ammonia added to $25 \mathrm{gm}$. of surface soil. Evaporated at $95-98^{\circ} \mathrm{C}$.)

\begin{tabular}{|c|c|c|c|c|}
\hline RHODE ISLAND PLAT & $\frac{1}{2}$ HOUR & 1 HOUR & 4 EOURS & 10 HOURS \\
\hline 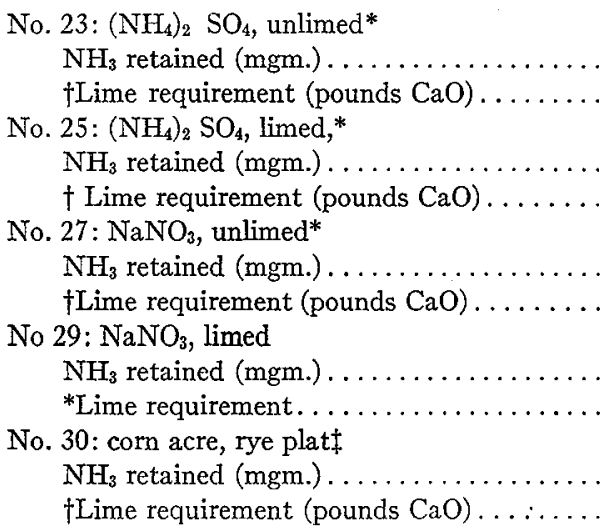 & $\begin{array}{c}18.56 \\
2,441\end{array}$ & $\begin{array}{c}52.56 \\
6,925 \\
\\
39.84 \\
5,249 \\
\\
41.95 \\
5,527 \\
\\
28.35 \\
3,735 \\
\\
19.38 \\
2,573\end{array}$ & $\begin{array}{c}52.08 \\
6,862 \\
40.12 \\
5,286 \\
42.70 \\
5,428 \\
4 \\
29.44 \\
3,879\end{array}$ & $\begin{array}{c}52.97 \\
6,979 \\
\\
41.20 \\
5,428 \\
\\
43.04 \\
5,670 \\
\\
28.49 \\
3,753\end{array}$ \\
\hline
\end{tabular}

* Surface soil, 8 inches deep, collected June 29, 1916.

$\dagger$ Requirement of $2,000,000$ pounds soil.

$\$$ Soil 12 inches deep, collected June 10,1915 , evaporated at $60^{\circ}$ to $65^{\circ} \mathrm{C}$.

TABLE 2

Retention of ammonia dependent upon temperature of evaporation. $[25 \mathrm{gms}$. soil, $170 \mathrm{mgm}$. ammonia (volume $50 \mathrm{cc}$.), 1 hour contact]

\begin{tabular}{|c|c|c|c|c|}
\hline \multirow[b]{2}{*}{. } & \multicolumn{2}{|c|}{$65-75^{\circ} \mathrm{C}}$. & \multicolumn{2}{|c|}{$95-98^{\circ} \mathrm{C}$} \\
\hline & $\underset{\text { retained }}{\mathrm{NH}_{3}}$ & $\begin{array}{l}\text { Lime re- } \\
\text { quirement* }\end{array}$ & $\begin{array}{c}\mathrm{NH}_{3} \\
\text { retained }\end{array}$ & $\begin{array}{c}\text { Lime re- } \\
\text { quirement }\end{array}$ \\
\hline & $m g m$. & lbs. & $m g m$. & lbs. \\
\hline 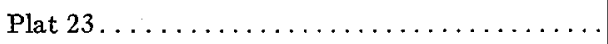 & 52.56 & 6,925 & 52.22 & 6,880 \\
\hline 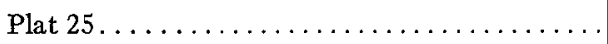 & 40.66 & 5,357 & 39.98 & 5,267 \\
\hline Plat $27 \ldots \ldots \ldots$ & 43.38 & 5,715 & 43.79 & 5,769 \\
\hline Plat $29 \ldots \ldots \ldots \ldots$ & 30.39 & 4,007 & 28.08 & 3,699 \\
\hline Corn acre rye plat. $\ldots \ldots \ldots \ldots \ldots \ldots$ & 19.92 & 2,629 & 17.68 & 2,329 \\
\hline
\end{tabular}

*Requirement of $2,000,000$ pounds of soil in pounds $\mathrm{CaO}$.

more ammonia is held by physical forces. Combinations with very weak organic acids might exist, which would decompose at the higher temperature.

In the smaller application of ammonia quite wide variation in retention results. In amounts of 170 to $340 \mathrm{mgm}$., the influence upon retention is practically negligible. 
TABLE 3

Retention dependent upon mass of ammonia added. (25 gm. soil, 1 hour contact, temperature $95-98^{\circ} \mathrm{C}$.)

\begin{tabular}{|c|c|c|c|c|c|c|c|c|}
\hline & \multicolumn{2}{|c|}{$\begin{array}{l}85 \text { MGM. NH3 } \\
\text { ADDED }\end{array}$} & \multicolumn{2}{|c|}{$\begin{array}{c}170 \text { MGM. NII3 } \\
\text { ADDED }\end{array}$} & \multicolumn{2}{|c|}{$\begin{array}{l}255 \text { MGM. NH3 } \\
\text { ADDED }\end{array}$} & \multicolumn{2}{|c|}{$\begin{array}{l}340 \text { MGM. NH3 } \\
\text { ADDED }\end{array}$} \\
\hline & $\begin{array}{c}\mathrm{NH}_{3} \\
\text { taine- }\end{array}$ & $\begin{array}{c}\text { Lime } \\
\text { require- } \\
\text { ment }^{*}\end{array}$ & $\mid \begin{array}{c}\mathrm{NH}_{3} \text { re- } \\
\text { tained }\end{array}$ & \begin{tabular}{|} 
Lime \\
require- \\
ment**
\end{tabular} & $\underset{\text { tained }}{\mathrm{NH}_{3}}$ & $\begin{array}{c}\text { Lime } \\
\text { require- } \\
\text { ment* }\end{array}$ & $\begin{array}{c}\mathrm{NH}_{3} \mathrm{re} \\
\text { tained }\end{array}$ & $\begin{array}{l}\text { Lime } \\
\text { require- } \\
\text { ment* }\end{array}$ \\
\hline & $m g m$. & $l b s$. & $m g m$. & $l b s$ & $m g m$. & $l b s$. & $m g m$. & $l b s$ \\
\hline Plat $23 \ldots$ & 45.49 & 5,993 & 51.74 & 6,817 & 53.04 & 6,988 & 53.38 & 7,033 \\
\hline Plat $25 \ldots$. & 32.91 & 4,336 & 39.16 & 5,159 & 40.52 & 5,338 & 40.18 & 5,294 \\
\hline Plat 27. & 33.45 & 4,407 & 43.65 & 5,751 & 43.04 & 5,670 & 42.77 & 5,635 \\
\hline \multirow[t]{3}{*}{ Plat $29 \ldots \ldots \ldots \ldots \ldots \ldots$} & 22.37 & 2,947 & 26.77 & 3,527 & 27.47 & 3,619 & 28.49 & 3,753 \\
\hline & \multicolumn{2}{|c|}{$\begin{array}{l}70 \underset{\text { ADDED }}{\mathrm{MGM}} \mathrm{NH}_{3} \\
\text { ADED }\end{array}$} & \multicolumn{2}{|c|}{$\begin{array}{l}140 \text { MGM. NH3 } \\
\text { ADDED }\end{array}$} & \multicolumn{2}{|c|}{$\begin{array}{c}210 \text { MGM. NB3 } \\
\text { ADDED }\end{array}$} & \multicolumn{2}{|c|}{$\begin{array}{l}280 \text { MGM. NH3 } \\
\text { ADDED }\end{array}$} \\
\hline & $\mid \begin{array}{c}\mathrm{NH}_{3} \text { re- } \\
\text { tained }\end{array}$ & $\begin{array}{c}\text { Lime } \\
\text { require- } \\
\text { ment } \dagger\end{array}$ & $\mid \begin{array}{c}\mathrm{NH}_{3} \text { re- } \\
\text { tained }\end{array}$ & $\begin{array}{c}\text { Time } \\
\text { require- } \\
\text { ment } \dagger\end{array}$ & $\begin{array}{c}\mathrm{NH}_{3} \\
\text { tained }\end{array}$ & $\begin{array}{c}\text { Lime } \\
\text { require- } \\
\text { ment } \dagger\end{array}$ & $\mid \begin{array}{c}\mathrm{NH}_{3} \\
\text { tained }\end{array}$ & $\begin{array}{c}\text { Lime } \\
\text { require- } \\
\text { ment } \dagger\end{array}$ \\
\hline Corn acre, rye plat $\uparrow$. & $\begin{array}{l}m g m . \\
19.38\end{array}$ & $\begin{array}{c}l b s . \\
2,573\end{array}$ & $\begin{array}{l}m g m . \\
20.74\end{array}$ & $\begin{array}{c}l b s . \\
2,732\end{array}$ & $\begin{array}{l}m g m . \\
23.12\end{array}$ & $\begin{array}{c}l b s . \\
3,046\end{array}$ & $\begin{array}{l}m g m . \\
23.12\end{array}$ & $\begin{array}{c}\text { lbs. } \\
3,046\end{array}$ \\
\hline
\end{tabular}

* Requirement of $2,000,000$ pounds of soil in pound $\mathrm{CaO}$.

$\dagger$ Temperature 60 to $65^{\circ} \mathrm{C}$.

\section{METHOD}

Treat $25 \mathrm{gm}$. of soil in an evaporating dish with $50 \mathrm{cc}$. N/5 NH $4 \mathrm{OH}$. Stir the mixture occasionally during a period of one hour. Evaporate the solution to dryness on a water bath containing boiling water. Rub the soil up with a pestle and allow it to remain upon the bath for $1 \frac{1}{2}$ hours. Wash the soil into a $500 \mathrm{cc}$. Kjeldahl flask with $100 \mathrm{cc}$. of ammonia-free water. Add 5 to $10 \mathrm{gm}$. of sodium carbonate and distil by the aeration method [essentially the method used by Potter and Snyder (2)], keeping the flasks perpendicular and the bottom of the distillation tube slightly above the bottom of the flask. Absorb the liberated ammonia in $25 \mathrm{cc}$. N/5 $\mathrm{H}_{2} \mathrm{SO}_{4}$ diluted to $200 \mathrm{cc}$. Determine the excess acid by titration with $\mathrm{N} / 25 \mathrm{NH}_{4} \mathrm{OH}$, using alizarin red as indicator. Make blank determinations with each soil.

\section{DISCUSSION OF METHOD}

The procedure as outlined yields a requirement which is only slightly affected by wide variation in the conditions under which retention takes place. No other method tried by the writer begins to be so free from analytical weaknesses as the procedure outlined. In other soil types, however, it may fail absolutely to qualify even from a laboratory standpoint.

The real test, however, is what it will do in the way of indicating small variations in reaction, under field conditions. 
No definite correlation with crop yields can be offered at this time. It had been hoped that the method may be submitted to a comparison with a crop sensitive to small variations in acidity, but such data cannot be presented now.

A few laboratory experiments have been made to learn to what extent the retention of ammonia can be used as an index of the absorption for other bases.

\section{SUBSTTTUTION OF BASES}

The plan was to evaporate to dryness the soil treated with solutions of various alkalies and alkaline earths and record the effect upon ammonia retention. This was done in the case of sodium and potassium in the hydroxides, carbonates and chlorides, and with calcium and barium in the hydroxides.

The results indicated that the amount of ammonia retained was diminished in practically equivalent amounts when the soil was acted upon by the hydroxides and carbonates of sodium or potassium. It was diminished very slightly by the chlorides.

With barium and calcium hydroxide, the ammonia absorption was diminished only about one-half what it should have been when figured on the equivalent basis. Their reaction was much slower than that of the alkalies, and it was probably not complete. Some of the solution was probably carbonated and rendered inactive and would thus neither enter into combination with the soil nor by force of its alkalinity drive off its equivalent amount of ammonia.

In general, those bases which tend to cause deflocculation and dissolve organic matter are held in equivalent amounts as measured by the subsequent ammonia retention, while those bases which cause flocculation and become carbonated in the process of evaporation do not react in this way.

\section{ABSORPTION OF AMMONIA BY CARBON BLACK}

The well-known power of finely divided particles to hold gases upon their surfaces by physical forces led to the question of what the absorptive power of a substance like carbon black would be under the conditions existing in the method.

Consequently, $45 \mathrm{mgm}$. of ammonia in a volume of $50 \mathrm{cc}$. were evaporated from $5 \mathrm{gm}$. of carbon black. A blank determination of ammonia in the carbon black itself was made after evaporating with $50 \mathrm{cc}$. water.

\begin{tabular}{|c|c|}
\hline & AMMONIA RECOVERED \\
\hline 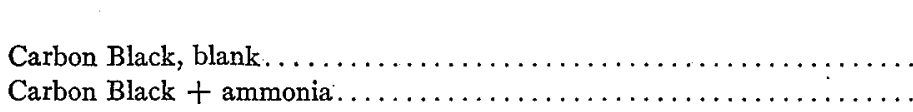 & $\begin{array}{c}m g m . \\
6.59 \\
5.84\end{array}$ \\
\hline
\end{tabular}


It is seen that no ammonia is held under these conditions and it is believed therefore that little ammonia is retained physically by the soils under similar treatment.

Comparison with the Veitch method

\begin{tabular}{|c|c|c|}
\hline \multirow[t]{2}{*}{$\cdot$} & \multicolumn{2}{|c|}{$\begin{array}{c}\text { REQUIREMENT POUNDS CaO PER } \\
2,000,000 \text { POUNDS SOIL }\end{array}$} \\
\hline & Ammonia method & Veitch method \\
\hline Plat 23. . & 6,925 & 8,714 \\
\hline Plat 25.. & 5,249 & 5,810 \\
\hline Plat $27 \ldots$ & 5,527 & 8,070 \\
\hline Plat $29 \ldots \ldots \ldots \ldots \ldots \ldots$ & 3,735 & 4,842 \\
\hline
\end{tabular}

The requirement indicated by the ammonia method runs consistently lower, the greatest variation being in the case of soil from plat 27 . The requirement indicated by the Veitch method for this soil is comparatively too high as measured by crop yields.

Soils treated according to the Veitch method yield an aqueous extract more alkaline than the extract of soils after evaporation with ammonia, which is nearly neutral.

\section{ABSORPTION OF AMMONIA BY SOILS}

After the completion of this paper there appeared in the literature a publication by Cook treating of the "Absorption of Ammonia by Soils" (3). The purpose of the present paper did not permit a review of the theories relative to ammonia absorption. The paper referred to makes such a contribution.

In the course of that paper it was pointed out that the application of calcium and sodium hydroxide resulted in an increased ammonia absorption in all cases but one. In the present paper it is shown that a decrease in retention of ammonia results from each of these treatments. It is desired merely to emphasize at this time that the method of procedure was entirely different, as given in two papers. Cook was working with solutions of ammonium sulfate at room temperature, while in the present work ammonium hydroxide was used and the excess eliminated at the temperature of boiling water.

The equilibrium that is established under Cook's treatment is referred to as being dependent upon numerous factors, among which are physical, physicochemical, chemical and perhaps biological. The absorption which results from his procedure indicates that these factors are active.

In the present paper it is pointed out that the retention of ammonia which results from the equilibrium established by the procedure outlined is dependent upon fewer factors and seems to follow the direction of true chemical reaction.

Attention is called to Cook's work, and especially to the difference in procedure, lest a hasty review of his paper should give the idea that it is incompatible to use the "Retention of Ammonia" as an index of lime requirements. 


\section{SUMMARY AND CONCLUSIONS}

A procedure is outlined for determining the lime requirements of soils, which consists in treating the soils with ammonium hydroxide, evaporating off the excess ammonia at a temperature of boiling water, and estimating the retained ammonia.

Within reasonable limits the requirement based upon this retention was independent of (a) concentration of ammonia added, (b) time of contact, and (c) temperature during evaporation.

The requirement was about 25 per cent lower than that indicated by the Veitch method.

Aeration in the presence of sodium carbonate for 18 hours (300 liters of air per hour) is sufficient to remove completely 50 to $75 \mathrm{mgm}$. of ammonia from the soil.

Sodium, ammonium and potassium from solutions of their hydroxides and carbonates are retained in practically equivalent amounts.

It is believed that the ammonia retained is held chemically by a neutralization of either free acids, acid organic compounds or acid salts, while physical absorption is largely prevented.

The "requirement" based upon the ammonia retention agreed in general with field observations, to the extent that soils needing the most lime showed the greatest "requirement."

\section{REFERENCES}

(1) Kober, P. A. 1913 Nephelometry in the study of proteases, II. In Jour. Amer. Chem. Soc., 35, no. 3, p. 290-292.

(2) Potrer, R. S. AND SNYDER, R. S. 1914 The determination of ammonia in soils, Iowa Agr. Exp. Sta. Res. Bul. 17.

(3) Сoor, R. C. 1916 Factors affecting the absorption and distribution of ammonia applied to soils. In Soil Sci., v. 2, p. 305-344. 